\title{
Article \\ Coprostanol as a Population Biomarker for SARS-CoV-2 Wastewater Surveillance Studies
}

\author{
Liam J. Reynolds ${ }^{1,+}$, Laura Sala-Comorera ${ }^{1,+}{ }^{\mathbb{D}}$, Mohd Faheem Khan ${ }^{1}$, Niamh A. Martin ${ }^{1}$, Megan Whitty ${ }^{1}$, \\ Jayne H. Stephens ${ }^{1}$, Tristan M. Nolan ${ }^{1}$, Eadaoin Joyce ${ }^{2}$, Nicola F. Fletcher ${ }^{3}$, Cormac D. Murphy ${ }^{1}$ D \\ and Wim G. Meijer ${ }^{1, *}$
}

\section{check for}

updates

Citation: Reynolds, L.J.;

Sala-Comorera, L.; Khan, M.F.; Martin, N.A.; Whitty, M.; Stephens, J.H.; Nolan, T.M.; Joyce, E.; Fletcher, N.F.; Murphy, C.D.; et al. Coprostanol as a Population Biomarker for SARS-CoV-2 Wastewater Surveillance Studies. Water 2022, 14, 225. https:// doi.org/10.3390/w14020225

Academic Editor: Helvi

Heinonen-Tanski

Received: 6 December 2021

Accepted: 10 January 2022

Published: 13 January 2022

Publisher's Note: MDPI stays neutral with regard to jurisdictional claims in published maps and institutional affiliations.

Copyright: (C) 2022 by the authors. Licensee MDPI, Basel, Switzerland. This article is an open access article distributed under the terms and conditions of the Creative Commons Attribution (CC BY) license (https:// creativecommons.org/licenses/by/ $4.0 /)$.
1 UCD School of Biomolecular and Biomedical Science, UCD Earth Institute and UCD Conway Institute, University College Dublin, D04 V1W8 Dublin, Ireland; liam.reynolds@ucd.ie (L.J.R.); laura.sala-comorera@ucd.ie (L.S.-C.); mohd.khan@ucd.ie (M.F.K.); niamh.martin1@ucd.ie (N.A.M.); Megan.whitty@ucd.ie (M.W.); jayne.stephens@ucdconnect.ie (J.H.S.); Tristan.nolan@ucdconnect.ie (T.M.N.); cormac.d.murphy@ucd.ie (C.D.M.)

2 Irish Water, Colvill House, 24-26 Talbot Street, D01 NP86 Dublin, Ireland; ejoyce@water.ie

3 UCD School of Veterinary Medicine, UCD Conway Institute, University College Dublin, D04 V1W8 Dublin, Ireland; nicola.fletcher@ucd.ie

* Correspondence: wim.meijer@ucd.ie; Tel.: +353-17-162-778

+ These authors contributed equally to this work.

\begin{abstract}
Wastewater surveillance is a cost-effective tool for monitoring SARS-CoV-2 transmission in a community. However, challenges remain with regard to interpretating such studies, not least in how to compare SARS-CoV-2 levels between different-sized wastewater treatment plants. Viral faecal indicators, including crAssphage and pepper mild mottle virus, have been proposed as population biomarkers to normalise SARS-CoV-2 levels in wastewater. However, as these indicators exhibit variability between individuals and may not be excreted by everyone, their utility as population biomarkers may be limited. Coprostanol, meanwhile, is a bacterial metabolite of cholesterol which is excreted by all individuals. In this study, composite influent samples were collected from a largeand medium-sized wastewater treatment plant in Dublin, Ireland and SARS-CoV-2 N1, crAssphage, pepper mild mottle virus, HF183 and coprostanol levels were determined. SARS-CoV-2 N1 RNA was detected and quantified in all samples from both treatment plants. Regardless of treatment plant size, coprostanol levels exhibited the lowest variation in composite influent samples, while crAssphage exhibited the greatest variation. Moreover, the strongest correlations were observed between SARS-CoV-2 levels and national and Dublin COVID-19 cases when levels were normalised to coprostanol. This work demonstrates the usefulness of coprostanol as a population biomarker for wastewater surveillance studies.
\end{abstract}

Keywords: SARS-CoV-2; coprostanol; PMMoV; crAssphage; wastewater surveillance; population biomarker

\section{Introduction}

Severe Acute Respiratory Syndrome Coronavirus 2 (SARS-CoV-2) is a positive sense single strand RNA respiratory virus that is the causative agent of COVID-19. Following the official declaration of the COVID-19 pandemic in March 2020, over 261 million individuals have been infected with the virus and over 5 million deaths have resulted at time of writing [1]. Disease symptoms range from fever and headaches to respiratory difficulties and pneumonia [2]. Diarrhoea may also be experienced by some individuals and SARSCoV-2 RNA has been detected in human faeces at concentrations up to $10^{7} \mathrm{RNA} / \mathrm{g}$, even after presentation of a negative pharyngeal swab [3,4].

The presence of SARS-CoV-2 RNA in the stool of symptomatic and asymptomatic individuals suggested that monitoring wastewater could be a useful means to determine 
the extent of community transmission of SARS-CoV-2 in a population [5,6]. Wastewater surveillance offers a cost-effective means to monitor transmission, as a single wastewater sample represents the entire population of the treatment plant's catchment. The first demonstration of wastewater surveillance to monitor SARS-CoV-2 was provided by Medema et al., who identified SARS-CoV-2 RNA in wastewater in the Netherlands prior to the first clinical cases [7]. SARS-CoV-2 RNA monitoring of wastewater has now been implemented in numerous countries to complement their national testing efforts and has also been used to identify the dominant circulating variants in wastewater treatment plant (WWTP) catchments [8-11].

Although wastewater surveillance has demonstrated its usefulness as a tool to monitor SARS-CoV-2 in communities, challenges still remain, particularly in how to meaningfully compare SARS-CoV-2 RNA levels between WWTPs of different catchment sizes. Thus, a means to normalise SARS-CoV-2 RNA to the amount of faecal material in the WWTP is required. Such a normalisation method would also benefit studies monitoring SARSCoV-2 in wastewater on smaller scales, such as university accommodation and meat processing facilities which have seen infection outbreaks $[12,13]$. Studies have used the WWTP catchment population to normalise SARS-CoV-2 concentrations [14,15]. However, as catchment populations vary due to commuting workers and tourism, the de jure population (WWTP catchment population) can significantly differ from the de facto population (the population actually contributing to a WWTP). The volume of water passing through a WWTP has also been used to determine the daily SARS-CoV-2 RNA loading in a number of systems. However, as many plants receive surface water, non-faeces contaminated grey water and industrial effluent, this does not appropriately reflect how much faecal material passes through a WWTP. Additionally, variability in faecal content may be greater in smaller WWTPs compared to large plants that receive a more homogenous sample of a catchment's faecal input which would not be captured by flow alone [16,17]. Furthermore, flow data is not always available for small WWTPs, student dormitories and meat processing facilities.

A number of molecular markers have been developed as indicators of human faecal pollution that may prove useful as population biomarkers for normalising SARS-CoV2 levels. For example, crAssphage and pepper mild mottle virus (PMMoV) are DNA and single-strand RNA viruses, respectively, that are present in high concentrations in human faeces [18-20]. PMMoV has been used to normalise SARS-CoV-2 levels in many wastewater surveillance studies. However, a recent study by Ahmed et al. demonstrated that crAssphage exhibited a lower coefficient of variance than PMMoV in 24-h composite wastewater samples, highlighting crAssphage as a useful normalising marker [21]. The HF183 microbial source tracking marker is a well-established molecular marker that targets the $16 \mathrm{~S}$ gene of Bacteroides spp. specific to the human gut. This marker has been widely used to identify human faeces pollution in various environments but has shown little use as a population biomarker in SARS-CoV-2 wastewater surveillance studies [22-24].

As an alternative to viral and bacterial faecal markers, chemical indicators of faecal contamination may prove useful as a means to determine faecal loading in WWTPs. Faecal sterols ( $5 \beta$-stanols), for example, originate from the metabolism of cholesterol by gut microorganisms. Coprostanol $(5 \beta$-cholestan- $3 \beta-\mathrm{ol})$ is the most abundant $5 \beta$-stanol in human faeces representing approximately $60 \%$ of the sterol content of faeces [25]. Due to its abundance and ubiquity in human faeces, coprostanol has been proposed as a population biomarker for wastewater epidemiology studies [22,26].

Currently, there is no consensus on how to accurately incorporate the population contributing to a WWTP in SARS-CoV-2 wastewater surveillance studies. Thus, the aim of this study was to assess the utility of PMMoV, crAssphage and HF183 faecal markers and coprostanol, as population biomarkers to normalise SARS-CoV-2 RNA levels to human faecal input in a large- and medium-sized WWTP. 


\section{Methods}

\subsection{Sample Sites and Sample Collection}

Between October 2020 and February 2021 time-weighted (hourly) $24 \mathrm{~h}$ composite wastewater influent samples $(n=10)$ were collected from both the Ringsend and Shanganagh WWTPs using a refrigerated autosampler. Samples were stored on ice and processed within $6 \mathrm{~h}$ on the day of collection. Both plants receive influent from the greater Dublin area. The Ringsend WWTP is the largest WWTP in the Republic of Ireland and currently operates at a capacity of 1.98 million population equivalents, which represents approximately $40 \%$ of Ireland's population. The Shanganagh WWTP is a medium-size plant operating at 248,000 population equivalents. The flow data $\left(\mathrm{m}^{3} /\right.$ day) for each WWTP on the day of sampling was obtained from Irish Water.

\subsection{Composite Wastewater Influent Concentration and Nucleic Acid Extraction}

Composite wastewater influent samples were concentrated using $100 \mathrm{kDa}$ Centricon Plus-70 filters. Briefly, the filter devices were washed by filling with $70 \mathrm{~mL}$ of sterile distilled water and centrifuging at $3200 \times g$ for $5 \mathrm{~min}$. $250 \mathrm{~mL}$ of the composite wastewater influent samples were centrifuged at $3200 \times g$ for $30 \mathrm{~min}$ to remove solids. The resulting supernatant was then passed through the filters in $70 \mathrm{~mL}$ aliquots by centrifuging at $3200 \times g$ for 15-40 min at a time. Approximately $500 \mu \mathrm{L}$ of concentrated wastewater was recovered by inverting the filter into a collection tube and centrifuging at $1000 \times g$ for $2 \mathrm{~min}$. Concentrated wastewater samples were stored at $-20^{\circ} \mathrm{C}$ until nucleic acid extraction.

RNA was extracted from $250 \mu \mathrm{L}$ of concentrated wastewater using the RNeasy PowerMicrobiome Kit (Qiagen, Hilden, Germany) according to the manufacturer's protocols. DNA was extracted from $250 \mu \mathrm{L}$ of concentrated wastewater using the DNeasy PowerSoil kit (Qiagen) according to the manufacturer's guidelines. We validated this protocol using SARS-CoV-2 negative sewage spiked with heat inactivated SARS-CoV-2 and found recovery to range between $50 \%$ and $94.7 \%$, Table S1.

\section{3. qPCR Assays to Quantify SARS-CoV-2 RNA and Human Faecal Markers}

All qPCR assays were performed on the Roche LightCycler 96 platform (Roche Diagnostics, Basel, Switzerland). RT-qPCR assays were conducted in $20 \mu \mathrm{L}$ volumes using the LightCycler Multiplex RNA Virus Master (Roche Diagnostics, Basel Switzerland). For SARS-CoV-2 N1 and PMMoV assays, $5 \mu \mathrm{L}$ and $1 \mu \mathrm{L}$ of RNA was used in each assay, respectively. The crAssphage and HF183 markers were quantified in $20 \mu \mathrm{L}$ reactions using the FastStart Essential DNA Probes Master and FastStart Essential DNA Green Master (Roche Diagnostics, Mannheim, Germany), respectively. For both assays $1 \mu \mathrm{L}$ of DNA extraction (or a 10-fold dilution of the DNA extraction) was used as template. All samples, negative controls and extraction blanks were analysed in duplicate, while standards were included in triplicate in each 96-well plate. Results were expressed as gene copies ( $\mathrm{gc}) / 100 \mathrm{~mL}$. Reaction efficiencies for each assay were determined using the $\mathrm{E}=10^{(-1 / \text { slope })}$ equation [27]. The limit of detection (LOD) was determined as the lowest concentration of DNA detected in $95 \%$ or more of replicates and the limit of quantification (LOQ) was determined as the lowest concentration of DNA quantified within 0.5 standard deviations of the $\log 10$ concentration [28]. No amplification of targets was observed in negative controls. Primer sequences, cycling conditions, LODs, LOQs and standards information are included in Table 1.

\subsection{Quantification of Coprostanol}

$10 \mathrm{~mL}$ of each $24 \mathrm{~h}$ composite wastewater influent sample was extracted twice with $20 \mathrm{~mL}$ ethyl acetate using a $250 \mathrm{~mL}$ separating funnel. The solvent from the samples was removed under reduced pressure using a rotary evaporator and the residue was collected into $2 \mathrm{~mL}$ glass vials by re-dissolving in $1 \mathrm{~mL}$ of ethyl acetate. The samples were then dried under $\mathrm{N}_{2}$ gas and silylated using $100 \mu \mathrm{L}$ N-methyl-N-trimethylsilyltrifluoroacetamide (MSTFA) at $100{ }^{\circ} \mathrm{C}$ for $1 \mathrm{~h}$ before adjusting the final volume by 
adding $500 \mu \mathrm{L}$ ethyl acetate. For quantification of coprostanol in the influent samples, $5 \mu \mathrm{g}$ of testosterone was added as an internal standard. The silylated samples were analysed on the 7890B N Agilent GC system. The instrument was equipped with a HP-5MS capillary column $(30 \mathrm{~m} \times 0.25 \mathrm{~mm} \times 0.25 \mu \mathrm{m})$ and a 5977A mass-selective detector. $1 \mu \mathrm{L}$ of each sample was injected in the splitless mode; the oven temperature was initially set at $120{ }^{\circ} \mathrm{C}$ for $2 \mathrm{~min}$ then raised to $300^{\circ} \mathrm{C}$ at $10{ }^{\circ} \mathrm{C} / \mathrm{min}$ rate with solvent delay for $5 \mathrm{~min}$. The resulting peak areas of coprostanol in the influent samples were compared to that of the internal standard to determine concentrations. Coprostanol concentrations were determined by comparing the coprostanol peak to the internal testosterone standard on the resulting chromatograms (Figure S1).

Table 1. Primers, cycling conditions, amplicon and standard information, assay parameters, Limit of Detection (LoD) and Quantification (LoQ) for the qPCR assays used in this study.

\begin{tabular}{|c|c|c|c|c|c|c|}
\hline Target Gene & Primer Sequence & $\begin{array}{l}\text { Cycling } \\
\text { Conditions }\end{array}$ & $\begin{array}{l}\text { Amplicon Size } \\
\text { (Standard) }\end{array}$ & $\begin{array}{c}\text { Slope/y- } \\
\text { Intercept } / \mathbf{R}^{2}\end{array}$ & $\begin{array}{l}\text { Reaction } \\
\text { LoD (LoQ) }\end{array}$ & Reference \\
\hline SARS-CoV-2 N1 & $\begin{array}{c}\text { F: GACCCCAAAATCAGC- } \\
\text { GAAAT } \\
\text { R: TCTGGTTACT- } \\
\text { GCCAGTTGAATCTG } \\
\text { Probe: } \\
\text { FAM- } \\
\text { ACCCCGCATTACGTTTGGT- } \\
\text { GGACC-BHQ1 }\end{array}$ & $\begin{array}{l}\text { RT }\left(50{ }^{\circ} \mathrm{C}-600 \mathrm{~s}\right) \\
95^{\circ} \mathrm{C}-30 \mathrm{~s}, \\
45 \text { cycles }\left(95^{\circ} \mathrm{C}\right. \\
\left.-5 \mathrm{~s}, 60^{\circ} \mathrm{C}-30 \mathrm{~s}\right)\end{array}$ & $\begin{array}{c}73 \text { bp } \\
\text { (2019-nCoV_N_Positive } \\
\text { Control Plasmid, } \\
\text { Integrated DNA } \\
\text { Technologies, Coralville, } \\
\text { IA, USA) }\end{array}$ & $\begin{array}{c}-3.2177 / \\
37.82 / 0.99\end{array}$ & $\begin{array}{c}5 \mathrm{gc} / \mu \mathrm{L} \\
(5 \mathrm{gc} / \mu \mathrm{L})\end{array}$ & [29] \\
\hline HF183 & $\begin{array}{c}\text { F: ATCATGAGTTCACAT- } \\
\text { GTCCG } \\
\text { R: TACCCCGCCTACTATC- } \\
\text { TAATG }\end{array}$ & $\begin{array}{l}45 \text { cycles }\left(95^{\circ} \mathrm{C}-\right. \\
5 \mathrm{~s}, 60^{\circ} \mathrm{C}-15 \mathrm{~s} \\
\left.72^{\circ} \mathrm{C}-20 \mathrm{~s}\right)\end{array}$ & $\begin{array}{c}82 \text { bp } \\
\text { (HF183 Amplicon } \\
\text { cloned into pBLUE } \\
\text { Plasmid, linear, } \\
\text { Addgene, Watertown, } \\
\text { MA, USA) }\end{array}$ & $\begin{array}{l}-3.4902 / \\
40.2 / 1.00\end{array}$ & $\begin{array}{c}1.1 \mathrm{gc} / \mu \mathrm{L} \\
(2.2 \mathrm{gc} / \mu \mathrm{L})\end{array}$ & [30] \\
\hline crAssphage & $\begin{array}{c}\text { F: CAGAAGTACAAACTCC- } \\
\text { TAAAAAACGTAGAG } \\
\text { R: GATGACCAATAAA- } \\
\text { CAAGCCATTAGC } \\
\text { Probe: } \\
\text { FAM- } \\
\text { AATAACGATTTACGTGA- } \\
\text { TGTAAC-MGB }\end{array}$ & $\begin{array}{l}95^{\circ} \mathrm{C}-600 \mathrm{~s}, \\
40 \text { cycles }(95 \\
{ }^{\circ} \mathrm{C}-15 \mathrm{~s}, 60^{\circ} \mathrm{C}- \\
60 \mathrm{~s})\end{array}$ & $\begin{array}{c}126 \text { bp } \\
\text { (gBlock, Integrated } \\
\text { DNA Technologies, } \\
\text { Coralville, IA, USA) }\end{array}$ & $\begin{array}{c}-3.398 / \\
37.01 / 1.00\end{array}$ & $\begin{array}{c}4.7 \mathrm{gc} / \mu \mathrm{L} \\
(4.7 \mathrm{gc} / \mu \mathrm{L})\end{array}$ & [19] \\
\hline PMMoV & $\begin{array}{c}\text { F: GAGTGGTTTGACCT- } \\
\text { TAACGTTTGA } \\
\text { R: TTGTCGGTTGCAATG- } \\
\text { CAAGT } \\
\text { Probe:FAM- } \\
\text { CCTACCGAAGCAAATG- } \\
\text { BHQ1 }\end{array}$ & $\begin{array}{c}\text { RT }\left(50^{\circ} \mathrm{C}-600 \mathrm{~s}\right), \\
95^{\circ} \mathrm{C}-30 \mathrm{~s}, \\
45 \mathrm{cycles} \\
\left(95^{\circ} \mathrm{C}-15 \mathrm{~s},\right. \\
\left.60^{\circ} \mathrm{C}-60 \mathrm{~s}\right)\end{array}$ & $\begin{array}{c}68 \mathrm{bp} \\
\text { (gBlock, Integrated } \\
\text { DNA Technologies, } \\
\text { Coralville, IA, USA) }\end{array}$ & $\begin{array}{c}-3.2312 / \\
46.76 / 0.99\end{array}$ & $\begin{array}{c}160 \mathrm{gc} / \mu \mathrm{L} \\
(160 \mathrm{gc} / \mu \mathrm{L})\end{array}$ & {$[18,20]$} \\
\hline
\end{tabular}

\subsection{Data Analysis}

The concentrations (per $100 \mathrm{~mL}$ ) of the SARS-CoV-2 N1 marker, PMMoV, crAssphage, HF183, coprostanol and the volume flowing through each plant was used to determine the loading per day [concentration $(/ 100 \mathrm{~mL}) \times$ flow $\left.\left(\mathrm{m}^{3}\right) \times(10,000)\right]$. Daily loading per person of the SARS-CoV-2 N1 gene for each sample was calculated by dividing the daily loading by the population equivalent of the respective WWTP. The variation of SARS-CoV-2 and faecal indicator levels (gc/100 mL), SARS-CoV-2 daily loadings (gc/day) and SARS$\mathrm{CoV}-2$ daily loadings per person (gc/day/person) were determined as the coefficient of variation (CV). Official COVID-19 case data (date on which sample was confirmed positive) from the Health Protection Surveillance Centre and the Health Service Executive were obtained from COVID-19.geohive.ie. Spearman correlation analyses between the levels of $\mathrm{N} 1$ and N1 levels normalised to faecal indicators and new daily COVID-19 case numbers in Dublin and nationally on day $0,+/-1$ day and $+/-7$ days relative to the sample collection date were performed using Prism9 GraphPad software. Correlations between wastewater data from both WWTPs and Dublin cases were conducted as both plants are in Dublin and their catchments had comparable SARS-CoV-2 case rates during the study period (Ringsend 549 cases per $100 \mathrm{~K}$ and Shanganagh 417 cases per $100 \mathrm{~K}$ ). Correlations between 
wastewater and national clinical case data were conducted because the Ringsend WWTP receives wastewater from $40 \%$ of Ireland's population, and cases in Dublin, during this period, represented $32 \%$ of national cases. A significance cut-off of $p \leq 0.05$ was used for all analyses to identify statistically significant correlations.

\section{Results and Discussion}

\subsection{SARS-CoV-2 N1 RNA Can Be Quantified in Large and Medium WWTP Influent}

During the sampling period, between October 2020 and February 2021, the SARS-CoV-2 N1 RNA amplicon could be detected in composite influent wastewater samples from both WWTPs on all dates. Concentrations ranged from 1450-12,100 gc/100 mL at Ringsend. Concentrations at Shanganagh were up to 3-fold lower, 552-8540 gc/100 mL (Table 2, Figure S2a). Although monitoring concentrations of SARS-CoV-2 RNA can provide insight into the extent of circulation of the virus in a catchment, it does not include any information on the population contributing faecal matter in the catchment. Many studies reporting SARS-CoV-2 levels have taken the daily volume of water in the WWTP into account presenting daily SARS-CoV-2 loadings. Indeed, when flow was considered the loading of SARS-CoV-2 N1 RNA in Ringsend $\left(9.24 \times 10^{12}-7.95 \times 10^{13} \mathrm{gc} /\right.$ day $)$ was 10 -fold greater than those observed in Shanganagh $\left(2.94 \times 10^{11}-4.48 \times 10^{12} \mathrm{gc} /\right.$ day; Table 2, Figure S2b). Interestingly, when SARS-CoV-2 N1 gene loadings are normalised to their respective treatment plant catchment population Ringsend levels $\left(4.67 \times 10^{6}-4.02 \times 10^{7} \mathrm{gc} /\right.$ day/person) were approximately 3-fold greater than Shanganagh $\left(1.19 \times 10^{6}-1.81 \times 10^{7} \mathrm{gc} /\right.$ day/person $)$, which is similar to the observation of SARS-CoV-2 N1 concentrations (Table 2, Figure S2c).

Table 2. The minimum, maximum and median concentrations and daily loadings of SARS-CoV-2 N1 RNA as well as the coefficients of variation (CV) for Ringsend and Shanganagh WWTPs over the sampling period of this study.

\begin{tabular}{|c|c|c|c|c|c|c|c|c|c|c|c|c|}
\hline \multirow{2}{*}{$\begin{array}{l}\text { Wastewater } \\
\text { Treatment } \\
\text { Plant }\end{array}$} & \multicolumn{4}{|c|}{$\begin{array}{l}\text { SARS-CoV-2 RNA Concentration } \\
\text { (gc/100 mL) }\end{array}$} & \multicolumn{4}{|c|}{ SARS-CoV-2 RNA Daily Loading (gc/day) } & \multicolumn{4}{|c|}{$\begin{array}{l}\text { SARS-CoV-2 RNA Daily Loading Per Person } \\
\text { (gc/day/person) }\end{array}$} \\
\hline & Median & Min. & Max. & $\mathrm{CV}$ & Median & Min. & Max. & $\mathrm{CV}$ & Median & Min. & Max. & $\mathrm{CV}$ \\
\hline Ringsend & 4355 & 1450 & 12,100 & $65.93 \%$ & $2.32 \times 10^{13}$ & $9.24 \times 10^{12}$ & $7.95 \times 10^{13}$ & $82.18 \%$ & $1.17 \times 10^{7}$ & $4.67 \times 10^{6}$ & $4.01 \times 10^{7}$ & $82.24 \%$ \\
\hline Shanganagh & 1890 & 552 & 8540 & $99.56 \%$ & $8.25 \times 10^{11}$ & $2.94 \times 10^{11}$ & $4.48 \times 10^{12}$ & $107.7 \%$ & $3.32 \times 10^{6}$ & $1.19 \times 10^{6}$ & $1.81 \times 10^{7}$ & $107.9 \%$ \\
\hline
\end{tabular}

The increased disparity between observed Ringsend and Shanganagh SARS-CoV-2 N1 RNA levels when flow is used to determine daily loadings highlights that this approach is not suited to analyses comparing WWTPs of different sizes. Additionally, using WWTP flow rates to estimate the population contributing faecal matter is flawed, as a catchment's population demonstrates diurnal and weekly variations as people travel to and from work for example. This results in a variability in the daily loading of faecal matter in a WWTP which would not be reflected by flow alone, particularly when individuals commute between WWTP catchments [31]. Furthermore, WWTPs receive surface water from rivers as well as grey water and industrial effluent that do not reflect the population of the plant catchment and will thus dilute faecal matter [26]. Thus, representing SARS-CoV-2 RNA data as daily loadings does not adequately represent the contribution of faecal matter in the system. When daily flow is normalised to the catchment population of the WWTP, the disparity between Ringsend and Shanganagh SARS-CoV-2 N1 RNA levels is similar to that observed for concentration; however, such an approach does not account for the movement of people between catchments.

\subsection{Faecal Indicators Are Abundant in Composite Influent}

To estimate the amount of faecal material within the sewer system of the two WWTPs studied in this work, two viral faecal indicators (crAssphage and PMMoV), one bacterial faecal indicator (HF183) and coprostanol, a chemical faecal indicator, were quantified from the collected $24 \mathrm{~h}$ composite influent samples to assess their use as population biomarkers. All faecal indicators could be detected and quantified in the composite influent from both WWTPs on all of the sampling dates. The viral and bacterial faecal indicators were present 
at levels significantly higher than those of SARS-CoV-2 N1. This is to be expected, as faecal indicators are typically present in higher concentrations in wastewater than circulating pathogens [32]. In both WWTPs, crAssphage was present in the highest concentrations $\left(1.18 \times 10^{6}-1.93 \times 10^{9} \mathrm{gc} / 100 \mathrm{~mL}\right)$, followed by PMMoV $\left(2.30 \times 10^{7}-3.49 \times 10^{8} \mathrm{gc} / 100 \mathrm{~mL}\right)$ and HF183 $\left(2.32 \times 10^{6}-6.08 \times 10^{7} \mathrm{gc} / 100 \mathrm{~mL}\right.$; Figure 1). These concentrations are in agreement with other studies that have demonstrated crAssphage to be more abundant than PMMoV and HF183 in wastewater influent [32,33]. Coprostanol concentrations ranged from 16.1-105 $\mu \mathrm{g} / 100 \mathrm{~mL}$ in the composite influent of both WWTPs.

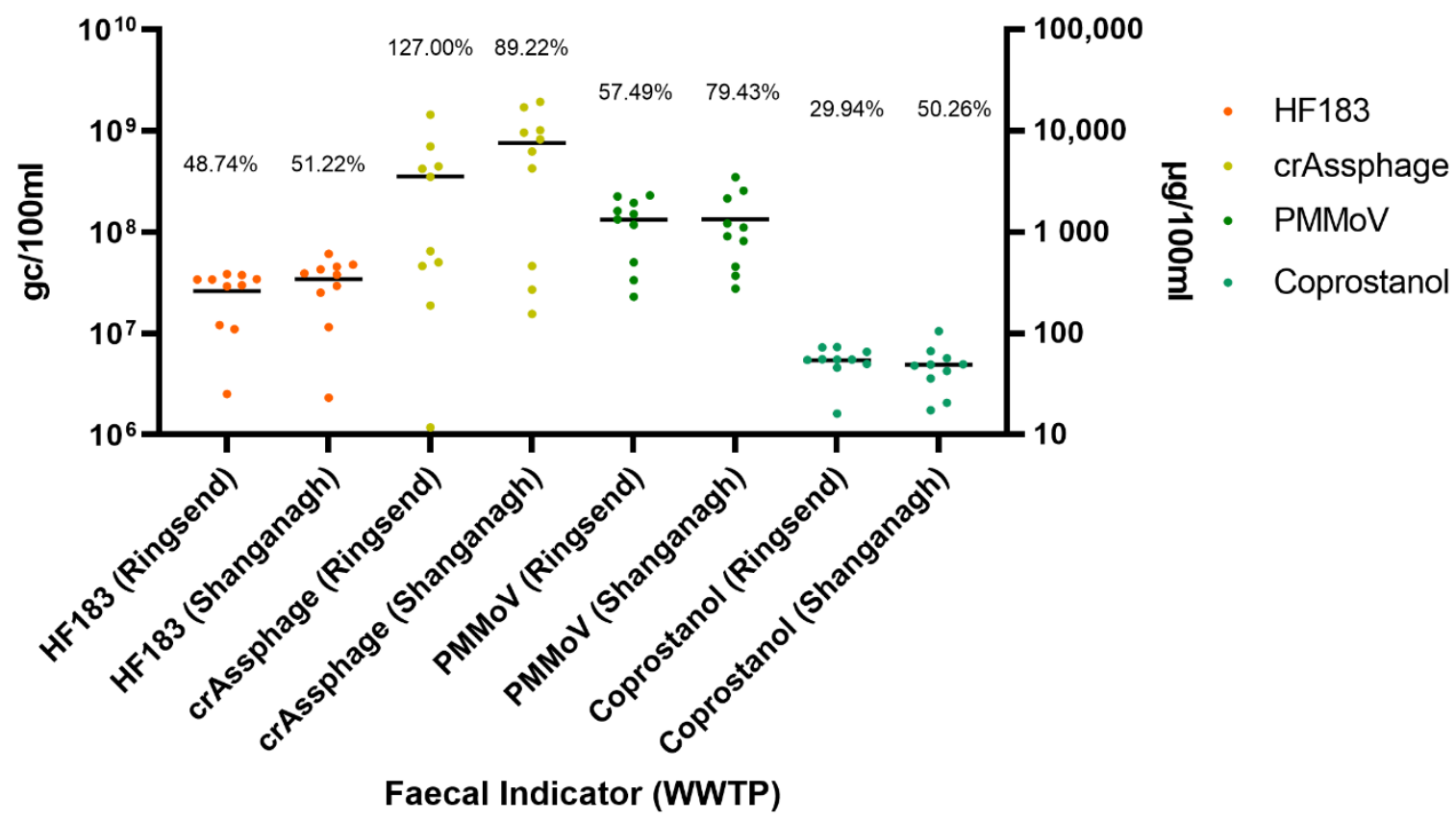

Figure 1. Dot plots showing the concentrations of HF183, crAssphage, pepper mild mottle virus (PMMoV) and coprostanol in both Ringsend and Shanganagh WWTPs. Coefficients of variation (CV) for each indicator and each WWTP are shown as percentages over each dot plot. HF183, crAssphage and PMMoV concentrations are illustrated as gc/100 mL (left Y-axis). Coprostanol levels are given as $\mu \mathrm{g} / 100 \mathrm{~mL}$ (right Y-axis).

\subsection{Coprostanol Concentrations Exhibit Less Variability than Viral and Bacterial Faecal Indicators}

For a faecal indicator to be useful as a population biomarker, it must exhibit a suitably stable signal in the collected wastewater sample. Thus, the biomarker must be excreted at a relatively stable rate per capita within the WWTP catchment area while displaying resilience to degradation in the sewer network [34]. crAssphage, in addition to exhibiting the highest concentrations in wastewater influent, also had the highest variation of the studied faecal indicators with CVs of $127 \%$ for Ringsend and $89.22 \%$ for Shanganagh (Figure 1). Variation was also high for PMMoV in Ringsend (57.49\%) and Shanganagh (79.42\%). Both HF183 and coprostanol demonstrated less variation than crAssphage and PMMoV. CVs of $48.74 \%$ and $51.22 \%$ were observed for HF183 in Ringsend and Shanganagh respectively. The lowest CVs, for both WWTPs, were exhibited by coprostanol, $29.94 \%$ in Ringsend and $50.36 \%$ in Shanganagh.

The higher variability of crAssphage and PMMoV compared to HF183 and coprostanol may result from these viruses being relatively more susceptible to degradation in wastewater systems; however, there are other factors that are likely contributing to the observed variability of these markers.

PMMoV, as a single-strand RNA virus, has been suggested as a faecal indicator that is useful as a population biomarker in SARS-CoV-2 wastewater surveillance studies as it is excreted in high levels from humans and has a stable RNA signal in various environments, including in wastewater [22,35-37]. D'Aoust et al. also demonstrated PMMoV RNA levels 
to be more stable than HF183 DNA levels, although these were primary sludge analyses rather than composite influent [22]; however, $\mathrm{PMMoV}$ is a plant virus and not a commensal of the human gut. Thus, its prevalence and abundance in wastewater will vary based on the dietary intake of the population of the wastewater system catchment. This likely explains the high degree of variability of PMMoV observed in this study.

Similarly, crAssphage-normalised SARS-CoV-2 levels have been reported and associations between these normalised levels and clinical case numbers in New York have been described [38]. Although crAssphage infects Bacteroides spp. that are normal commensals of the human gut, the prevalence of this host in the human gut may vary within and between WWTP catchments. Indeed, it is interesting to note that our observations are counter to what was observed in a Brisbane WWTP, where the crAssphage signal was found to be more stable than the PMMoV signal [21].

Such variations may result from global differences in the prevalence and excretion of PMMoV and the commensal crAssphage and HF183 encoding Bacteroides spp. in the guts of individuals. Thus, the utility of these viral and bacterial faecal indicators as population biomarkers is not universal and may vary by country [39].

Coprostanol has been suggested as an alternative method to estimate faecal loading in sewer systems and has seen use an indicator of human faecal pollution of environmental waters [40,41]. Furthermore, unlike viral and bacterial faecal markers which are indicators for the presence of commensal intestinal bacteria and viruses, coprostanol is a direct metabolite of a human molecule, cholesterol, that is produced by all individuals $[25,34]$. However, few studies have looked at its variability in wastewater and to the best of our knowledge none have experimentally assessed it as a population biomarker to normalise circulating pathogens, including SARS-CoV-2 [26,42]. Of the four faecal indicators assessed in this study, coprostanol had the lowest within WWTP variation, measured as CV. A key attribute of any population biomarker is that they should exhibit little variation; thus, coprostanol may provide utility as a novel alternative to viral and bacterial population biomarkers in wastewater epidemiology studies, including those monitoring SARS-CoV-2 [43,44].

Variation in faecal indicator concentrations was typically greater in the smaller Shanganagh WWTP compared to Ringsend, except for crAssphage. Previous studies have demonstrated that there are greater variations in faecal indicator concentrations between individuals than there are between wastewater samples $[25,45,46]$. Ballesté et al., for example, observed the HF183 faecal indicator to vary over five orders of magnitude between individual faecal samples, whereas the marker ranged within one order of magnitude in wastewater [47]. Thus, the lower variation of faecal indicators observed in the Ringsend composite influent samples may be due to this WWTP receiving faecal matter from a larger population which is more homogenous. As coprostanol levels displayed the lowest variation of the tested faecal indicators even in the smaller Shanganagh WWTP, it may prove to be a more useful population biomarker even for smaller WWTPs or within network sites where flow is a poor proxy for population.

The high concentrations of crAssphage and PMMoV indicate their usefulness as sensitive faecal indicator population biomarkers to normalise SARS-CoV-2 as part of a wastewater surveillance programme. However, the lower within and between plant variability of HF183 and particularly, coprostanol, concentrations provide evidence that they may act as robust alternative population biomarkers to normalise SARS-CoV-2 concentrations allowing for better longitudinal and between WWTP comparisons.

\subsection{Coprostanol-Normalised SARS-CoV-2 N1 Levels Correlate with National and Dublin Case Numbers}

Wastewater surveillance of a pathogen's genetic material offers a cost-effective means to monitor the extent of community transmission of a pathogen in a community. It also has the potential to predict future increases in clinical case numbers as individuals may shed the pathogen in their faeces prior to the onset of symptoms and receiving a positive test result. In the case of SARS-CoV-2, Peccia et al. observed increases in the virus' RNA signal 
in wastewater preceding an increase in positive clinical results by 6 to 8 days. On the other hand, Weidhaas et al. demonstrated that declining clinical COVID-19 cases were followed by a decrease in SARS-CoV-2 RNA levels [48-50]. To assess if SARS-CoV-2 N1 RNA levels correlated with daily new cases (both nationally and in Dublin only), correlations between normalised and non-normalised SARS-CoV-2 N1 levels and daily new cases $0,+/-1$ and $+/-7$ relative to the sampling day were conducted.

In the Ringsend composite influent samples, N1 RNA concentrations (gc/100 mL) and daily loadings (gc/day) exhibited strong and statistically significant correlations $\left(\mathrm{R}^{2}>0.65 ; p \leq 0.05\right)$ with new daily clinical cases in Dublin on day 0 and -7 relative to the sampling date as well as to new national daily cases on day +1 relative to the sampling date (Figure 2). In the Shanganagh composite influent samples, strong and statistically significant correlations were observed only between new daily cases in Dublin on day -7 relative to sampling date and N1 RNA concentrations and daily loadings (Figure 2). The correlations between SARS-CoV-2 N1 RNA concentrations and loadings in Ringsend composite influent and daily new cases supports previous studies that have demonstrated similar relationships between wastewater surveillance and clinical case number data [35,49]. That there were fewer correlations between Shanganagh SARS-Cov-2 N1 RNA concentrations and loadings and new daily cases compared to Ringsend, however, may be a result of differences in flow characteristics, residence time within the sewer network and faecal material content between the WWTPs. Such differences make comparisons between WWTPs using only SARS-CoV-2 concentrations or loadings a flawed endeavour and further highlights the need for an appropriate population biomarker that can correct for surface water, grey water and industrial discharges that can dilute faecal matter.

Ringsend

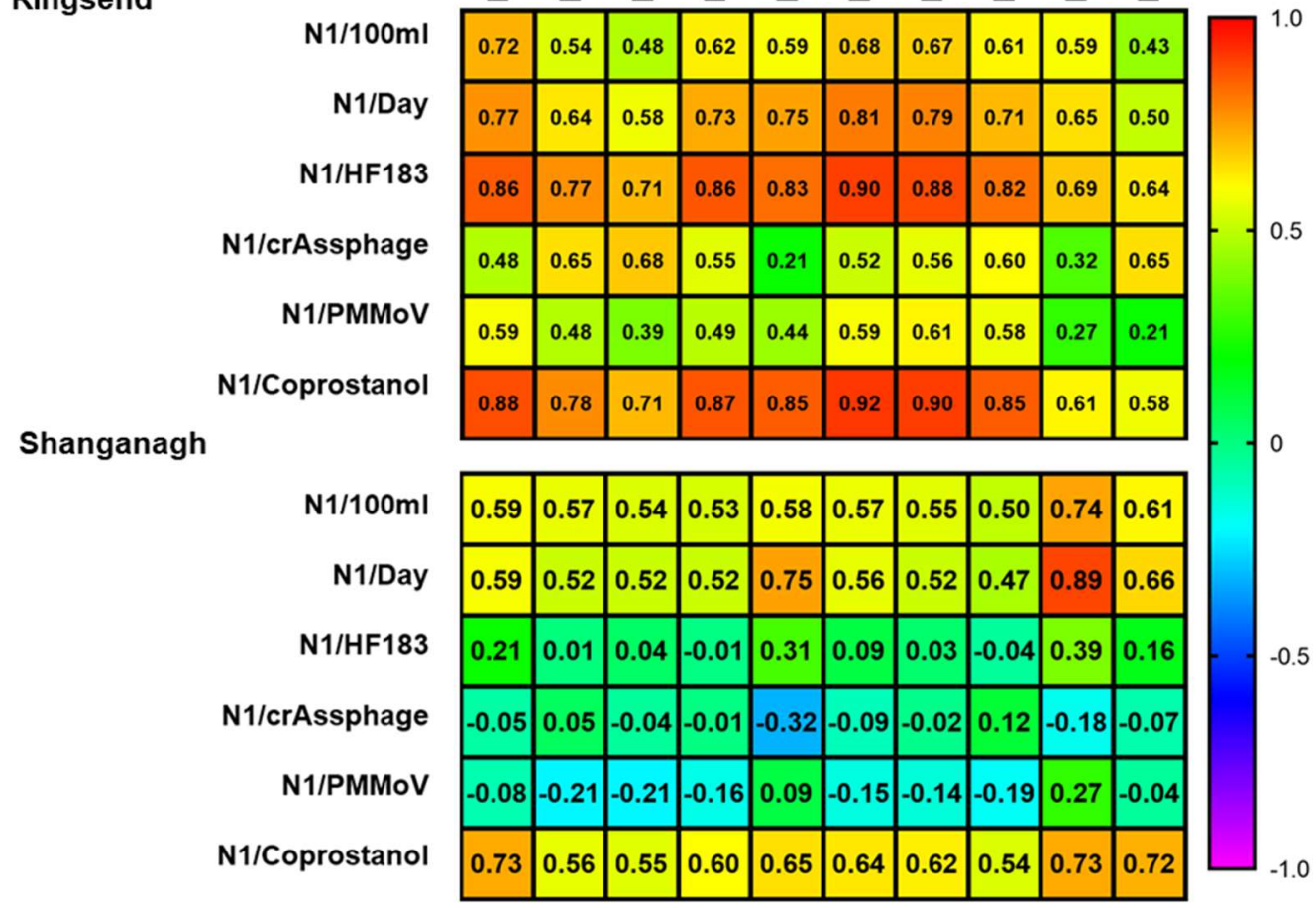

Figure 2. Heatmap showing correlations between normalised and non-normalised SARS-CoV-2 levels in Ringsend and Shanganagh and national and Dublin COVID-19 cases. $R^{2}$ coefficients $>0.65$ were considered as indicating strong correlations with a statistically significant cut-off of $p<0.05$. 
In this study, however, when SARS-CoV-2 N1 RNA levels were normalised to PMMoV and crAssphage levels, correlations with new daily cases were much weaker in Ringsend and Shanganagh (Figure 2). Although previous studies have presented crAssphage and PM$\mathrm{MoV}$ as useful markers to normalise SARS-CoV-2 RNA concentrations, our study provides evidence that these faecal indicators may not act as universal population biomarkers [38,51]. These results corroborate our earlier findings that the high variation exhibited by these two faecal indicators make them inappropriate population biomarkers.

Interestingly, when SARS-CoV-2 was normalised to HF183 levels in Ringsend, statistically significant correlations were observed with new daily national and Dublin SARSCoV-2 cases on day $0,-/+1$ and $-/+7$. The opposite was observed in the Shanganagh WWTP where no correlations were observed with new daily cases when N1 RNA concentrations were normalised to HF183 (Figure 2). This result is similar to what was observed by D'Aoust et al., who noted that when SARS-CoV-2 N1 RNA levels were normalised to PMMoV, there were stronger correlations with clinical cases numbers in a WWTP in Ottawa but not in Gatineau [22].

Similarly, when normalised to coprostanol concentrations, N1 RNA levels exhibited statistically significant correlations with new national and Dublin SARS-CoV-2 cases on day $0,-/+1$ and $-/+7$ for the Ringsend WWTP. Additionally, normalising Shanganagh SARSCoV-2 RNA levels to coprostanol concentrations identified stronger correlations between $\mathrm{N} 1$ and new cases in Dublin on day 0 and +7 and national cases on day -1 . Together these correlations provide further evidence that HF183 and, in particular, coprostanol show utility as alternative population biomarkers to crAssphage and PMMoV. It is interesting to note that coprostanol-normalized N1 levels highlighted a relationship between SARS-CoV-2 RNA and clinical cases numbers in both Ringsend and Shanganagh, while normalising N1 concentrations to HF183 highlighted such correlations in Ringsend only. This may be a result of the smaller size of Shanganagh compared to Ringsend, meaning it takes in faecal matter from a smaller population and as such is less homogenised. This observation coupled with coprostanol exhibiting the lowest variation of the tested faecal indicators, even in the medium size Shanganagh WWTP, suggests that coprostanol may be a superior population biomarker than crAssphage, PMMoV and HF183 even when dealing with smaller WWTPs.

\section{Conclusions}

To conclude, using coprostanol as a population biomarker to normalise SARS-CoV-2 N1 RNA levels would provide a way to make more meaningful comparisons of SARSCoV-2 surveillance data between WWTP's of difference size. Furthermore, in the absence of flow data, for example when monitoring wastewater at sites receiving waste from a small population, such as meat processing factories and university dormitories, which have been documented as sites of SARS-CoV-2 transmission, coprostanol may prove useful as a population biomarker $[12,13]$.

Supplementary Materials: The following supporting information can be downloaded at: https: / / www.mdpi.com/article/10.3390/w14020225/s1, Figure S1: Chromatograms depicting coprostanol peaks; Figure S2: Concentration of the SARS-CoV-2 N1 marker and daily loadings of SARS-CoV-2 N1 marker; Table S1: Recovery efficiency of SARS-CoV-2 from heat inactivated SARS-CoV-2 spiked sewage samples.

Author Contributions: Methodology: L.J.R., L.S.-C., M.F.K., N.F.F., C.D.M. and W.G.M.; data analysis and curation: L.J.R., L.S.-C., M.F.K., N.A.M., M.W., J.H.S. and T.M.N.; writing-original draft preparation: L.J.R. and W.G.M.; writing—review and editing: L.J.R., L.S.-C., W.G.M., N.F.F., C.D.M. and E.J.; funding acquisition: W.G.M. All authors have read and agreed to the published version of this manuscript.

Funding: This research (Acclimatize) was part funded by the European Regional Development Fund through the Ireland Wales Cooperation Programme and by Science Foundation Ireland (20-CoV-8460).

Conflicts of Interest: The authors have no conflict of interest to declare. 


\section{References}

1. WHO. Coronavirus Disease (COVID-19) Pandemic Dashboard; WHO: Geneva, Switzerland. Available online: https:/ / covid19.who. int/ (accessed on 1 December 2021).

2. Grant, M.C.; Geoghegan, L.; Arbyn, M.; Mohammed, Z.; McGuinness, L.; Clarke, E.L.; Wade, R.G. The prevalence of symptoms in 24,410 adults infected by the novel coronavirus (SARS-CoV-2; COVID-19): A systematic review and meta-analysis of 148 studies from 9 countries. PLoS ONE 2020, 15, e0234765. [CrossRef]

3. Wölfel, R.; Corman, V.M.; Guggemos, W.; Seilmaier, M.; Zange, S.; Muller, M.A.; Niemeyer, D.; Jones, T.C.; Vollmar, P.; Rothe, C.; et al. Virological assessment of hospitalized patients with COVID-2019. Nature 2020, 581, 465-469. [CrossRef]

4. Chen, Y.; Chen, L.; Deng, Q.; Zhang, G.; Wu, K.; Ni, L.; Yang, Y.; Liu, B.; Wang, W.; Wei, C.; et al. The presence of SARS-CoV-2 RNA in the feces of COVID-19 patients. J. Med. Virol. 2020, 92, 833-840. [CrossRef]

5. $\quad$ Bivins, A.; Greaves, J.; Fischer, R.; Yinda, K.C.; Ahmed, W.; Kitajima, M.; Munster, V.J.; Bibby, K. Persistence of SARS-CoV-2 in Water and Wastewater. Environ. Sci. Technol. Lett. 2020, 7, 937-942. [CrossRef]

6. Sala-Comorera, L.; Reynolds, L.J.; Martin, N.A.; O'Sullivan, J.J.; Meijer, W.G.; Fletcher, N.F. Decay of infectious SARS-CoV-2 and surrogates in aquatic environments. Water Res. 2021, 201, 117090. [CrossRef] [PubMed]

7. Medema, G.; Heijnen, L.; Elsinga, G.; Italiaander, R.; Brouwer, A. Presence of SARS-Coronavirus-2 RNA in Sewage and Correlation with Reported COVID-19 Prevalence in the Early Stage of the Epidemic in The Netherlands. Environ. Sci. Technol. Lett. 2020, 7, 511-516. [CrossRef]

8. $\quad$ Ahmed, W.; Angel, N.; Edson, J.; Bibby, K.; Bivins, A.; O’Brien, J.W.; Choi, P.M.; Kitajima, M.; Simpson, S.L.; Li, J.; et al. First confirmed detection of SARS-CoV-2 in untreated wastewater in Australia: A proof of concept for the wastewater surveillance of COVID-19 in the community. Sci. Total Environ. 2020, 728, 138764. [CrossRef]

9. Hata, A.; Hara-Yamamura, H.; Meuchi, Y.; Imai, S.; Honda, R. Detection of SARS-CoV-2 in wastewater in Japan during a COVID-19 outbreak. Sci. Total Environ. 2021, 758, 143578. [CrossRef]

10. Wurtzer, S.; Waldman, P.; Levert, M.; Mouchel, J.M.; Gorgé, O.; Boni, M.; Maday, Y.; Marechal, V.; Moulin, L. Monitoring the propagation of SARS CoV2 variants by tracking identified mutation in wastewater using specific RT-qPCR. medRxiv 2021. [CrossRef]

11. Crits-Christoph, A.; Kantor, R.S.; Olm, M.R.; Whitney, O.N.; Al-Shayeb, B.; Lou, Y.C.; Flamholz, A.; Kennedy, L.C.; Greenwald, H.; Hinkle, A.; et al. Genome Sequencing of Sewage Detects Regionally Prevalent SARS-CoV-2 Variants. mBio 2021, 12, e02703-e02720. [CrossRef] [PubMed]

12. Gunther, T.; Czech-Sioli, M.; Indenbirken, D.; Robitaille, A.; Tenhaken, P.; Exner, M.; Ottinger, M.; Fischer, N.; Grundhoff, A.; Brinkmann, M.M. SARS-CoV-2 outbreak investigation in a German meat processing plant. EMBO Mol. Med. 2020, 12 , e13296. [CrossRef]

13. Rennert, L.; McMahan, C.; Kalbaugh, C.A.; Yang, Y.; Lumsden, B.; Dean, D.; Pekarek, L.; Colenda, C.C. Surveillance-based informative testing for detection and containment of SARS-CoV-2 outbreaks on a public university campus: An observational and modelling study. Lancet Child Adolesc. Health 2021, 5, 428-436. [CrossRef]

14. Daughton, $\mathrm{C}$. The international imperative to rapidly and inexpensively monitor community-wide Covid-19 infection status and trends. Sci. Total Environ. 2020, 726, 138149. [CrossRef]

15. Hamouda, M.; Mustafa, F.; Maraqa, M.; Rizvi, T.; Aly Hassan, A. Wastewater surveillance for SARS-CoV-2: Lessons learnt from recent studies to define future applications. Sci. Total Environ. 2021, 759, 143493. [CrossRef] [PubMed]

16. Holcomb, D.A.; Stewart, J.R. Microbial Indicators of Fecal Pollution: Recent Progress and Challenges in Assessing Water Quality. Curr. Environ. Health Rep. 2020, 7, 311-324. [CrossRef] [PubMed]

17. Garcia-Aljaro, C.; Blanch, A.R.; Campos, C.; Jofre, J.; Lucena, F. Pathogens, faecal indicators and human-specific microbial source-tracking markers in sewage. J. Appl. Microbiol. 2019, 126, 701-717. [CrossRef] [PubMed]

18. Haramoto, E.; Kitajima, M.; Kishida, N.; Konno, Y.; Katayama, H.; Asami, M.; Akiba, M. Occurrence of pepper mild mottle virus in drinking water sources in Japan. Appl. Environ. Microbiol. 2013, 79, 7413-7418. [CrossRef]

19. Stachler, E.; Kelty, C.; Sivaganesan, M.; Li, X.; Bibby, K.; Shanks, O.C. Quantitative CrAssphage PCR Assays for Human Fecal Pollution Measurement. Environ. Sci. Technol. 2017, 51, 9146-9154. [CrossRef] [PubMed]

20. Zhang, T.; Breitbart, M.; Lee, W.H.; Run, J.-Q.; Wei, C.L.; Soh, S.W.L.; Hibberd, M.L.; Liu, E.T.; Rohwer, F.; Ruan, Y. RNA Viral Community in Human Feces: Prevalence of Plant Pathogenic Viruses. PLoS Biol. 2005, 4, e3. [CrossRef]

21. Ahmed, W.; Bivins, A.; Bertsch, P.M.; Bibby, K.; Gyawali, P.; Sherchan, S.P.; Simpson, S.L.; Thomas, K.V.; Verhagen, R.; Kitajima, M.; et al. Intraday variability of indicator and pathogenic viruses in 1-h and 24-h composite wastewater samples: Implications for wastewater-based epidemiology. Environ. Res. 2021, 193, 110531. [CrossRef]

22. D'Aoust, P.M.; Mercier, É.; Montpetit, D.; Jia, J.-J.; Alexandrov, I.; Neault, N.; Baig, A.T.; Mayne, J.; Zhang, X.; Alain, T.; et al. Quantitative analysis of SARS-CoV-2 RNA from wastewater solids in communities with low COVID-19 incidence and prevalence. medRxiv 2020. [CrossRef] [PubMed]

23. Reynolds, L.J.; Sala-Comorera, L.; Martin, N.A.; Nolan, T.M.; Stephens, J.H.; Gitto, A.; O'Hare, G.M.P.; O'Sullivan, J.J.; Meijer, W.G. Correlation between antimicrobial resistance and faecal contamination in small urban streams and bathing waters. Sci. Total Environ. 2020, 739, 140242. [CrossRef] 
24. Sala-Comorera, L.; Reynolds, L.J.; Martin, N.A.; Pascual-Benito, M.; Stephens, J.H.; Nolan, T.M.; Gitto, A.; O’Hare, G.M.P.; O'Sullivan, J.J.; García-Aljaro, C.; et al. crAssphage as a human molecular marker to evaluate temporal and spatial variability in faecal contamination of urban marine bathing waters. Sci. Total Environ. 2021, 789, 147828. [CrossRef]

25. Leeming, R.; Ball, A.; Ashbolt, N.; Nichols, P. Using faecal sterols from humans and animals to distinguish faecal pollution in receiving waters. Water Res. 1996, 30, 2893-2900. [CrossRef]

26. Daughton, C.G. Real-time estimation of small-area populations with human biomarkers in sewage. Sci. Total Environ. 2012, 414, 6-21. [CrossRef] [PubMed]

27. Rutledge, R.G.; Côté, C. Mathematics of quantitative kinetic PCR and the application of standard curves. Nucleic Acids Res. 2003, 31, e93. [CrossRef] [PubMed]

28. Rutledge, R.G.; Stewart, D. Critical evaluation of methods used to determine amplification efficiency refutes the exponential character of real-time PCR. BMC Mol. Biol. 2008, 9, 96. [CrossRef] [PubMed]

29. CDC. 2019-Novel Coronavirus (2019-nCoV) Real-Time rRT-PCR Panel Primers and Probes. Available online: https://www.cdc gov/coronavirus / 2019-ncov/downloads/rt-pcr-panel-primer-probes.pdf (accessed on 1 July 2020).

30. Seurinck, S.; Defoirdt, T.; Verstraete, W.; Siciliano, S.D. Detection and quantification of the human-specific HF183 Bacteroides 16S rRNA genetic marker with real-time PCR for assessment of human faecal pollution in freshwater. Environ. Microbiol. 2005, 7 , 249-259. [CrossRef] [PubMed]

31. Baz-Lomba, J.A.; Di Ruscio, F.; Amador, A.; Reid, M.; Thomas, K.V. Assessing Alternative Population Size Proxies in a Wastewater Catchment Area Using Mobile Device Data. Environ. Sci. Technol. 2019, 53, 1994-2001. [CrossRef]

32. Korajkic, A.; McMinn, B.; Herrmann, M.P.; Sivaganesan, M.; Kelty, C.A.; Clinton, P.; Nash, M.S.; Shanks, O.C. Viral and Bacterial Fecal Indicators in Untreated Wastewater across the Contiguous United States Exhibit Geospatial Trends. Appl. Environ. Microbiol. 2020, 86, e02967-19. [CrossRef]

33. Tandukar, S.; Sherchan, S.P.; Haramoto, E. Applicability of crAssphage, pepper mild mottle virus, and tobacco mosaic virus as indicators of reduction of enteric viruses during wastewater treatment. Sci. Rep. 2020, 10, 3616. [CrossRef]

34. Daughton, C.G. Using biomarkers in sewage to monitor community-wide human health: Isoprostanes as conceptual prototype. Sci. Total Environ. 2012, 424, 16-38. [CrossRef] [PubMed]

35. Wu, F.; Zhang, J.; Xiao, A.; Gu, X.; Lee, W.L.; Armas, F.; Kauffman, K.; Hanage, W.; Matus, M.; Ghaeli, N.; et al. SARS-CoV-2 Titers in Wastewater Are Higher than Expected from Clinically Confirmed Cases. mSystems 2020, 5, e00614-e00620. [CrossRef]

36. Graham, K.E.; Loeb, S.K.; Wolfe, M.K.; Catoe, D.; Sinnott-Armstrong, N.; Kim, S.; Yamahara, K.M.; Sassoubre, L.M.; Mendoza Grijalva, L.M.; Roldan-Hernandez, L.; et al. SARS-CoV-2 RNA in Wastewater Settled Solids Is Associated with COVID-19 Cases in a Large Urban Sewershed. Environ. Sci. Technol. 2021, 55, 488-498. [CrossRef] [PubMed]

37. Haramoto, E.; Malla, B.; Thakali, O.; Kitajima, M. First environmental surveillance for the presence of SARS-CoV-2 RNA in wastewater and river water in Japan. Sci. Total Environ. 2020, 737, 140405. [CrossRef]

38. Green, H.; Wilder, M.; Collins, M.; Fenty, A.; Gentile, K.; Kmush, B.L.; Zeng, T.; Middleton, F.A.; Larsen, D.A. Quantification of SARS-CoV-2 and cross-assembly phage (crAssphage) from wastewater to monitor coronavirus transmission within communities. medRxiv 2020. [CrossRef]

39. Bivins, A.; Crank, K.; Greaves, J.; North, D.; Wu, Z.; Bibby, K. Cross-assembly phage and pepper mild mottle virus as viral water quality monitoring tools—potential, research gaps, and way forward. Curr. Opin. Environ. Sci. Health 2020, 16, 54-61. [CrossRef]

40. Lyons, B.P.; Devlin, M.J.; Abdul Hamid, S.A.; Al-Otiabi, A.F.; Al-Enezi, M.; Massoud, M.S.; Al-Zaidan, A.S.; Smith, A.J.; Morris, S.; Bersuder, P.; et al. Microbial water quality and sedimentary faecal sterols as markers of sewage contamination in Kuwait. Mar. Pollut. Bull. 2015, 100, 689-698. [CrossRef]

41. Carreon-Palau, L.; Parrish, C.C.; Perez-Espana, H. Urban sewage lipids in the suspended particulate matter of a coral reef under river influence in the South West Gulf of Mexico. Water Res. 2017, 123, 192-205. [CrossRef] [PubMed]

42. Chen, C.; Kostakis, C.; Gerber, J.P.; Tscharke, B.J.; Irvine, R.J.; White, J.M. Towards finding a population biomarker for wastewater epidemiology studies. Sci. Total Environ. 2014, 487, 621-628. [CrossRef] [PubMed]

43. Yang, Z.; Xu, G.; Reboud, J.; Kasprzyk-Hordern, B.; Cooper, J.M. Monitoring Genetic Population Biomarkers for Wastewater-Based Epidemiology. Anal. Chem. 2017, 89, 9941-9945. [CrossRef] [PubMed]

44. Daughton, C.G. Monitoring wastewater for assessing community health: Sewage Chemical-Information Mining (SCIM). Sci. Total Environ. 2018, 619-620, 748-764. [CrossRef] [PubMed]

45. Maldonado, C.; Venkatesan, M.I.; Phillips, C.R.; Bayona, J.M. Distribution of Trialkylamines and Coprostanol in San Pedro Shelf Sediments Adjacent to a Sewage Outfall. Mar. Pollut. Bull. 2000, 40, 680-687. [CrossRef]

46. Kitajima, M.; Sassi, H.P.; Torrey, J.R. Pepper mild mottle virus as a water quality indicator. NPJ Clean Water 2018, 1, 19. [CrossRef]

47. Ballesté, E.; Demeter, K.; Masterson, B.; Timoneda, N.; Sala-Comorera, L.; Meijer, W.G. Implementation and integration of microbial source tracking in a river watershed monitoring plan. Sci. Total Environ. 2020, 736, 139573. [CrossRef]

48. Weidhaas, J.; Aanderud, Z.T.; Roper, D.K.; VanDerslice, J.; Gaddis, E.B.; Ostermiller, J.; Hoffman, K.; Jamal, R.; Heck, P.; Zhang, Y.; et al. Correlation of SARS-CoV-2 RNA in wastewater with COVID-19 disease burden in sewersheds. Sci. Total Environ. 2021, 775, 145790. [CrossRef]

49. Peccia, J.; Zulli, A.; Brackney, D.E.; Grubaugh, N.D.; Kaplan, E.H.; Casanovas-Massana, A.; Ko, A.I.; Malik, A.A.; Wang, D.; Wang, M.; et al. Measurement of SARS-CoV-2 RNA in wastewater tracks community infection dynamics. Nat. Biotechnol. 2020, 38, 1164-1167. [CrossRef] [PubMed] 
50. Nemudryi, A.; Nemudraia, A.; Wiegand, T.; Surya, K.; Buyukyoruk, M.; Cicha, C.; Vanderwood, K.K.; Wilkinson, R.; Wiedenheft, B. Temporal Detection and Phylogenetic Assessment of SARS-CoV-2 in Municipal Wastewater. Cell Rep. Med. 2020, 1, 100098. [CrossRef]

51. Wolfe, M.K.; Archana, A.; Catoe, D.; Coffman, M.M.; Dorevich, S.; Graham, K.E.; Kim, S.; Grijalva, L.M.; Roldan-Hernandez, L.; Silverman, A.I.; et al. Scaling of SARS-CoV-2 RNA in Settled Solids from Multiple Wastewater Treatment Plants to Compare Incidence Rates of Laboratory-Confirmed COVID-19 in Their Sewersheds. Environ. Sci. Technol. Lett. 2021, 8, 398-404. [CrossRef] 